\title{
Does XBRL improve the quality of financial statements in the banking industry?
}

\author{
Hari Prasetyo ${ }^{1}$, R Nelly Nur Apandi² \\ Program Studi Akuntansi, FPEB, Universitas Pendidikan Indonesia, Bandung, Indonesia ${ }^{1}$ \\ Program Studi Akuntansi, FPEB, Universitas Pendidikan Indonesia, Bandung, Indonesia ${ }^{1}$
}

\begin{abstract}
This study aims to determine the influence of the complexity of the banking business on the quality of financial statements that are moderated by the XBRL reporting form on the banking industry sector listed on the Indonesia Stock Exchange in 2017. The sample used was 43 banking companies from a total of 91 financial sector companies, based on purposive sampling. The complexity of the banking business in this study is measured by the level of complexity of the BOOK based on OJK regulations No. 6 / POJK.03 / 2016, the quality of financial statements is measured using non-discretionary accruals, and XBRL is measured by the use of the company in that year. In analyzing data, this study uses statistical tests of multiple regression analysis. Based on the calculation of multiple regression analysis with the help of Eviews 10 software, the relationship between the complexity of the banking business and the quality of financial statements is strengthened by the form of XBRL reporting. This research contributes to the implementation of XBRL for enhancing the quality of Financial Statement.
\end{abstract}

Keyword. banking complexity; XBRL; quality of financial statement

Article History. Received August, 2019. Revised October, 2019.Accepted December, 2019

Corresponding Author. Email. mr.prsetyo@gmail.com ${ }^{1}$, nelly_nna@upi.edu ${ }^{2}$

\section{INTRODUCTION}

Quality information is an essensial resource for companies. Information that has a quality will help companies make the right decision. As revealed by Rahmawati (2012, p. 150), quality information can help investors predict returns that will be received within a specified period. Adjustments published by Byard \& Cebenoyan (2012) they say that the use of good and usable sources of information will increase the percentage of results accuracy.

One of the main sources of investment decision making is financial statements. Financial statements based on the Statement of Financial Accounting Standards (PSAK) are a structured presentation of the financial position and financial performance of an entity. The financial statements will be presented in the company's financial statements presented in numbers. Some financial statement formats contained in the statement of financial position are the statement of financial position, income statement or income statement, statement of cash flows, and statement of changes in equity.

Financial statements play an important role in the business world. It becomes important and becomes an expectation for investors in the decision-making process (Byard \& Cebenoyan, 2012). Byard \& Cebenoyan (2012) said that there is an increase in market demand for quality financial reports. It is related to quality financial statements that will be relevant evidence in viewing the company's performance in a period of time. A good financial report will provide accurate, verified, and trustworthy information so that investors easily determine investment decisions (Gramling \& Bailey, 2015).

The financial statements prepared will reflect the company's performance and financial health in a certain period (Lim et al., 2015). The quality of financial statements will make a bad assessment of the company and make it difficult to do an analysis of the financial statements (Lim et al., 2015). Bhattacharya et al. (2013) said that companies with poor 
accrual mapping into cash flow would reduce the quality of the information in their income statements.

Improved quality of financial statements in Indonesia began to be seen since 2015, last year began to be implemented with a system called Extensible Business Reporting Language (XBRL). One of these improvements can be seen from the revision/restatement of financial statements conducted by the issuer. From 2016 to 2017, companies listed on the Indonesia Stock Exchange showed the quality of financial statements that can be seen from the comparison of companies that make restatements. In 2016, 36 companies restated financial statements. This number increased significantly in 2017, with only one company doing restatement. Over the next five years, there have been several well-known cases that have dragged down large companies in Indonesia. Examples are the 2013-2014 BNI Syariah Bank case, Bank Bukopin, Toshiba, Garuda, and SNF Finance (Bank Mandiri). Most of the cases dragged companies from the banking industry. The banking industry is one of the sectors that most obeyed the rules because they are one of the industries that have strict requirements (BEI, 2014, p. 13).

Banking is one of the industries engaged in the financial services sector, which processes its business directly regulated by law. The main banking business activity is the payment system, where the payment system of the banking industry is demanded to be upto-date, healthy, transparent, and accountable, its activities (Latumaerissa, 2017, p. 82).

Latumaerissa $(2017$, p. 82) revealed that the industry has several challenges in developing its information system. It is intended to improve the quality of services provided to the public. Garbellotto (2009) said that the application of capital/resources owned depends on how the company implement the strategy.

To meet the desires of report users, accounting experts continue to develop financial accounting to suit their needs and can be more useful in decision making. Therefore, several classifications are made about the quality of financial statement (Harahap, 2010). The Banking Industry has its own way of classifying its industry. The classification is based on business agreements that it has the complexity of banking from core capital, business activities, equity participation, and office networks. The results of the classification will be entered into the BOOK list. The lowest BOOK List is BOOK 1, and the highest is BOOK 4. The results of the classification will be monitored and accessed annually (Financial Services Authority, 2015, p. 19).

According to Harymawan \& Nurillah (2017), the quality of the financial statements submitted is directly proportional to the level of difficulty of the business it has. In companies with good capital and labor resources, they will immediately increase the financial quality they have. For example, in the banking industry that is in line with BOOK 4 level, it will improve quality better with banks in BOOK 1.

In 2015, a new reporting format called Extensible Business Reporting Language or XBRL was introduced by the Indonesia Stock Exchange. The entry of XBRL into Indonesia, the start of a new era of approval in Indonesia (BEI, 2014, p. 11). XBRL is an electronic communication language or computer language that can help all electronic applications that are connected with the XML language. This language is a universal language used for the transmission and transfer of business information that requires processing, indexing and searching for applications, special parties that provide (companies/parties) and who use the business information (investors/regulators) (BEI, 2014, p. 12). The capital market industry's need for accurate and reliable information is increasingly high. Information is expected to be carried out in the process quickly without having to spend money and time in processing. Therefore XBRL is expected to be a factor in enhancing report quality (BEI, 2014, p. 15). 
Previous research that discusses financial reporting on financial reports provides diverse research results. For example, research that discuss the effect of company capital on the quality of financial statements, obtaining results that are significantly related, but in some studies that reveal research on the use of XBRL cannot or cannot be considered at all. Some results from this study can be based on sample selection, year period, and the tools used to express the relationship of the variables taken.

Harymawan and Nurillah (2017) conducted a study of the relationship between companies and the quality of financial statements produced. This research concludes that companies with high capital will positively influence the quality of financial statements supported. In the banking situation, the higher the BOOK level obtained will be the higher owned by the company. It is because this company will get permission to expand its business scope to various regions in Indonesia.

Research conducted by Kardan et al. (2016) about the effect of the relationship of capital ownership in the form of external funding results showed a negative relationship between the quality of financial statements issued against the capital needed by the company. The results of this study are slightly different from previous studies.

Several different results were also issued by some researchers who linked the XBRL reporting format to the quality of financial statements. As Shan et al.'s (2015) study, on the effect of XBRL on audit fees, the effect of XBRL moderation and firm size on audit fees in the United States and Japan. XBRL is inversely proportional to audit fees, whereas on company size is directly proportional to audit fees. Overall, XBRL moderates the relationship between company size and audit costs in Japan and the United States.

Researchers continue to express XBRL on improving the quality of financial statements is Gandoman \& Rostami (2014), which supports the development of the use of the XBRL reporting system on improving the quality of financial statements in Iran. XBRL, with the quality of financial statements in Iran, on the other hand, also improves the classification of financial transparency, access, and improvement.

Different results were revealed by Blankespoor et al. (2014), who said that the adoption of XBRL would increase asymmetric information for the early years, this is because it resulted in a transitional process carried out by operational companies to support this system. Companies are required to have adequate resources to implement XBRL. This effect is released on a larger company. Increased information asymmetry decreases in subsequent years.

The development of information technology that supports companies is not always responded positively by companies, companies need to take more time about the technology, and the company must prepare to start a new era by recruiting professionals to change the technology. The use of technology in banking reporting has several benefits including, increasing efficiency, saving costs, and being able to facilitate transactions in the network (Dangolani, 2011).

Steenkamp and Nel (2012) reveal their effects in South Africa, where the initial implementation of XBRL implements low interest. Adoption is gradual and boarding. This effect is similar to in Indonesia, the arrival of new technology is not always responded well, because the company must prepare everything to get the maximum benefit.

In this study, the authors are interested in conducting research on banking problems on the quality of financial statements with the relationship moderated by the XBRL reporting format. The reason for the interest in taking the topic is not research that directly links the use of XBRL to the quality of financial reports in the banking industry in Indonesia. The banking industry is well known for the binding agreements given for the quality of services provided to consumers (Financial Services Authority, 2015). The quality of financial 
statements produced by the banking industry will also be developed for its business. This division is based on several categories of authorized capital invested.

Iskandar (2008) mentioned several reports that should be made by banks:

1. Internal Report report to shareholders; report to the directors; report to the branch office and to the head office; other reports (financial reports, reports to OJK, etc).

2. External Reports: report to Bank Indonesia; Financial Reports for third parties (community); report to other agencies.

Financial reports produced by complex banks should provide higher quality financial reports. However, the ARA results can be seen from the difference where banks having a higher BOOK is no better / quality compared to banks with BUKU levels below. Another reason is the variety of research results obtained from research on financial statements and XBRL so that the authors are interested in doing research.

Based on the descriptions above, several questions arise in the following research, namely (1) How financial influence on the quality of financial statements? (2) How does the use of the XBRL report format affect the quality of financial statements? (3) What is the effect of finance on the quality of financial statements that are moderated by the XBRL reporting format?

Agency theory is the relationship and contact that occurs between the agent and the agent. Agency theory has that each individual has motivation based on the interests and interests of third parties and agents. Anthony \& Govindarajan (2012) say that agency theory will show that companies can be used as a box relationship (loosely defined) between resource holders, namely investors. This relationship began to emerge because of the roles referred to as agents and principals. Agents were management assigned to manage a company funded by investors/principals. The relationship between agents and agents does not always work well. This relationship is very risky. This relationship reflects corporate governance and business ethics. When the agents themselves do so, they will incur agency costs, that is, costs incurred to improve effective agent relationships. Therefore, agency theory emerged as the dominant model in the financial economy literature in its context, including business ethics.

Agency theory explains the relationship between agents and agents. Both of these roles support to carry out activities while the principal will employ an agent to manage the company or organization. But with saturation, there are differences in interests that make the relationship not go well. Delegation of authority from the main party to carry out / manage the company or organization into risky actions. Conflicts between principals and agents are commonly referred to as agency problems. It is due to asymmetric information and errors in information obtained between the principal and agents Anthony \& Govindarajan (2012).

According to Anthony \& Govindarajan (2012), agency theory is based on 3 (three) basic assumptions (1) Assumptions about human nature. Assumptions about human nature that represent human nature for selfishness, the interests of rationality, and risklessness. (2) Assumptions about Organization. Organizational assumptions are conflicts between members of the organization, efficiency as an assessment of productivity, and the existence of information asymmetry. (3) Assumptions about information. Assumptions about information are information that is seen as goods/commodities that can be sold and bought.

Information asymmetry is a situation where there are parties who know more about the information compared to other parties (Rahmawati, 2012, p. 70). Other notions of information asymmetry, according to Scoot in Rahmawati (2012, p. 71): 
"Sometimes one party in the trade will better understand the assets offered by the other party not knowing it. This compilation takes place in the market as necessary asymmetric information."

Information asymmetry occurs because the parties are superior compared to other parties (the owners/shareholders). These conditions can lead to the existence of parties who want to maximize their interests, then the existence of these causes an interest in the interests of several parties by the management.

According to Kasmir (2008, p. 35), banking is a company engaged in the financial sector, which means that banking is always associated with the financial sector. The main activity of banking is collecting funds from the wider community, which is commonly referred to as funding in the banking world, which means collecting funds is collecting or seeking funds by buying from the wider community.

Understanding the purchase of funds from the public is a strategy used by banks to be able to withdraw funds from the public (Kasmir, 2008). Banks practise various strategies to collect as many funds as possible and see as effectively as possible. The strategy is formulated into a product concept, a product that we usually encounter as savings, or other programs that offer benefits and ease of profit.

Banking is related to banks, institutions, business activities, and the manner and process of its business activities (Latumaerissa, 2011, p. 88). Banking in Indonesia runs its business processes using the principle of prudence. The main function of banking in Indonesia is as a collector and distributor of public funds aimed at supporting national development to improve the distribution of economic growth, and to improve the living standards of many people (Latumaerissa, 2011, p. 88). Banking, Pension, Pension, and Financial System Placement. So banking is sound, transparent, and can be accounted for (Latumaerissa, 2011, p. 88).

Banking in Indonesia is divided into several levels, where this level classifies banks to be different. The classification is based on core capital, business activities, office networks, and bank business plans. Banking classifications in the elements referred to as bank credit. The level of complexity in banking is referred to as the BOOK. Each book will be classified according to core capital, business activities, office networks, and bank business plans. Banking in Indonesia so far is divided into four categories of BOOKS.

The requested core capital is the minimum amount of capital that must be owned by banks offered in Indonesia. This capital is the cost used to build a bank. Book 1 is a bank with a capital of less than Rp. 1,000,000,000,000.00 (one trillion rupiahs), Book 2 is a bank with a capital of at least Rp. 1,000,000,000,000.00 to less than Rp. 5,000,000,000,000.00 (five trillion rupiahs), Book 3 is a bank with a capital of at least $\operatorname{Rp} 5,000,000,000,000$ up to less than Rp. 30,000,000,000,000.00 (thirty trillion rupiahs), in Book 4 is banking with a minimum of Rp. 30,000,000,000,000.00 (thirty trillion rupiahs).

The intended business activities are business activities carried out by conventional commercial banks, namely:

1. raising funds;

2. distribution of funds;

3. Trade finance;

4. Treasury activities;

5. activities in foreign currencies;

6. agency activities and cooperation;

7. Electronic payment and banking system activities;

8. capital participation activities;

9. Temporary capital participation in the context of saving credit;

10. other services; and 
11. Other activities that are commonly carried out by the Bank as long as regulations do not approve it.

Business activities of conventional commercial banks that can be carried out in each BOOK are stipulated:

BOOK 1 can only do:

1. Business Activities in Rupiah which include:

a. fundraising activities which are basic products or activities;

b. fund distribution activities which are basic products or activities;

c. Trade Finance Activities;

d. activities with limited cooperation for agency and collaboration;

e. payment system activities and electronic banking with limited payments;

f. temporary equity participation activities in the context of saving credit; and

g. other services;

2. Activities as a foreign exchange trader

3. Other activities that are classified as basic products or activities in Rupiah are commonly carried out by the Bank and are not in accordance with statutory regulations.

BOOK 2 can do:

1. Business Activities in Rupiah and foreign currencies:

a. fundraising activities carried out in BOOK 1;

b. fund distribution activities are carried out in BOOK 1 with broader approval;

c. Trade Finance Activities;

d. limited treasury activities; and other services;

2. Business Activities approved in BOOK 1 with broader approval to:

a. agency and cooperation; and

b. Electronic payment and banking system activities;

c. Equity participation activities in financial institutions in Indonesia;

d. Temporary capital investment activities in the context of saving credit; and

e. with the laws and regulations;

BOOK 3 may conduct all Company activities based on Article 4 both in Rupiah and in foreign currencies and equity participation in financial institutions in Indonesia and/or abroad limited to the Asian region;

BOOK 4 can carry out all activities based on Article 4 both in Rupiah and in foreign currencies and equity participation in financial institutions in Indonesia and/or all overseas regions with amounts greater than BOOK 3 .

The classification in the modulation requested is a capital investment for investment or a subsidiary's permit. For the classification based on the specified equity participation of:

1. BOOK 2 at a maximum of $15 \%$ (fifteen percent) of bank capital;

2. BOOK 3 is a maximum of $25 \%$ (twenty-five percent) of the Bank's capital; and

3. BOOK 4 is no higher than $35 \%$ (thirty-five percent) of the Bank's capital.

Classification as needed channeling credit or financing to productive businesses with the provisions:

1. the lowest of $55 \%$ (fifty-five percent) of total credit or financing, for BOOK 1 ;

2. the lowest $60 \%$ (sixty percent) of total credit or financing, for BOOK 2;

3. the lowest $65 \%$ (sixty-five percent) of total credit or financing, for BOOK 3; and 


\section{4. lowest $70 \%$ (seventy percent) of total credit or financing for BOOK 4.}

Extensible Business Reporting Language (XBRL) is an XML-based language created to solve data shuttle problems. In the world of business and data processing automation directly. XBRL is a collaborative work developed to make information standardized and adjusted to representations of financial statements, taxes, and reports on integrated business (Dykes and Tittel, 2005). XBRL is an XML language that is included in the presentation of interactive data. The purpose of XBRL is to approve and facilitate financial information as in financial statements. The communication carried out by XBRL must be arranged systematically in a conceptual taxonomy (Perdana, 2014).

The process of implementing the XBRL system in financial reporting is an innovation that is very useful in the business world. Exchange of business report information moves to a specific analysis for the company, starting from the analysis of the process to the cost that is not cheap. Therefore, to increase the various costs that must be carried out in this process, there is a discourse to do online reporting that is integrated with investors. Online financial reporting has the advantage of cost savings and is more effective in the delivery and various other facilities that make this innovation a special consideration for companies that do it. In the implementation process, there are several phases in the presentation of these financial statements online. This phase in online finance is divided into 3 phases, namely, the phase before XBRL (XBRL adoption phase), the transition phase (transition phase), and the XBRL adoption phase (widespread adoption of the XBRL phase) (Boritz and No, 2009).

At this phase, the usual financial statements are still presented in paper form-based or paper-based / physical. The financial statements become the source and the media, which becomes the source of the data that must be translated into the format desired by XBRL. The desired special format is HTML, PDF, DOC, and spreadsheet.

Transition Phase

In this phase, the company will first submit its financial statements in the form of a paper-based or desired format. The financial statements are made into paper-based, which are then translated into XBRL format using software that has supported this activity. These devices support XBRL Tagging Software.

In this phase, the information contained in the paper-based financial statements has been translated into XBRL scripts. XBRL has been completely integrated with company accounting information. With this model/format, the outputs of these financial statements are not only fixed on the standard reports, but companies/investors will easily sort out the information in accordance with the needs desired in the process of capturing results.

The main objective of the company is to earn profits and increase the value of the company (Rahmawati, 2012, p. 80). In the process of achieving these goals, the company will try to get information that can be useful and can be trusted. Rahmawati (2012, p. 80) says if a company needs information to conduct its business activities. According to Yadiati (2010), the financial statements presented and prepared by the management of a company to internal and external parties, which contain all business activities of a business entity. The financial statements are one of the accountability tools and management communication to the parties who need it.

The information contained in financial statements must contain facts that occur in the field. These facts are obtained from events that occurred in a certain period and reported in a report. There are two types of information contained in financial statements, namely qualitative and quantitative. Quantitative information will usually contain accounting and non-accounting information. Accounting information can be divided into three types, namely financial accounting information, management accounting information, and operating accounting information (Yadiati, 2010). 
Yadiati (2010) explains that financial accounting information has to have higher benefits compared to the costs of obtaining such information. This information should be understandable and understood by all decision-makers. Information that is useful for decision making has several essential elements, including relevance, reliability, and comparability. First quality financial statements are completeness. Also, quality financial reports must have quality information, as well. Quality information will be disclosed if the company reports the information following the rules of the quality of the financial statements, including relevant, understandable, test power, Neutral, timeliness, comparability and complete.

The main financial statements are based on accrual bases. Accounting standards require financial reporting using the accrual concept (Subramanyam \& Wild, 2010). The definition of accruals is the amount of an accounting adjustment that makes net income different from net cash flow. These adjustments include adjustments that affect earnings when there are no cash flow impacts and adjustments that issue the impact of cash flows on earnings (Subramanyam \& Wild, 2010). Because it affects paired journals, accruals affect the balance sheet through an increase or decrease in the same amount of asset or liability accounts.

Subramanyam and Wild (2010) say that the general meaning of accruals is accounting adjustments that change the operating cash flow to net profit. This definition produces an identity for accruals in the form of Net profit $=$ Operating cash flow + Accrual. Based on this definition, accruals are divided into short-term accruals (short term accruals) related to working capital, as well as long-term accruals, such as depreciation and amortization.

The accrual basis will provide a better picture of the company's performance, so the company can make policies that are more relevant to the future. Accrual accounting consists of two basic principles of acknowledgment of income and the linking of expenses that direct the company about when to recognize revenues and expenses (Subramanyam \& Wild, 2010).

1. Recognition of income

Revenues are recognized, both when they are earned and when they are realized. Revenue occurs when a company submits a product or service. This means that the company has done its job. Revenue can be realized when a company obtains assets that can be converted into cash and cash equivalents from the delivery of goods and services.

2. Linking load

Accrual accounting requires the association of expenses with income. This attribution process is different for the two types of load. Expenses that arise from the production of a product or service are called product costs. These are recognized when the product is served. All product costs will remain on the balance sheet as inventories until they are sold and at the same time transferred to the income statement as cost of goods sold.

The conceptual advantage of accrual accounting compared to cash flow is that profit and loss and accrual-based balance sheets are more relevant for measuring the company's capacity to generate cash now and in the future (Subramanyam \& Wild, 2010). Accrual accounting overcomes the limitations of free cash flow by capitalizing investments in longterm assets and allocating costs throughout the useful life period. The advantages of accruals in presenting relevant information on the performance and financial condition of a company are explained as follows:

1. Financial performance

150 | The International Journal of Business Review (The Jobs Review) Vol.2 | No.2 | 2019 
Revenue recognition and attribution of costs produce profit figures that are superior to cash flow for evaluating financial performance. Revenue recognition ensures that expenses recorded in one period are only expenses related to income for that period.

2. Financial conditions

Accrual accounting results in a balance sheet that reflects more accurately the resources available to an enterprise to generate cash flows in the future.

The difference in determining the quality of financial statements is according to the wishes of the users of financial statements. It is obviously of the many interests given to a financial statement presented. The role of quality financial statements will decrease asymmetric information between company founders, management, the general public, and other users of financial statements.

Technological developments in financial reporting with development, companies are required to make reporting on operational activities in a transparent manner and prioritize the interests of investors. This situation is inversely proportional to what is desired by management. Management requests a form that supports both parties with the company while maintaining confidentiality and credibility. XBRL provides an option for investors and management in accordance with these interests so that both parties are not entitled to be harmed. XBRL began entering Indonesia in 2014 with socialization on the format of the report.

The use of XBRL is considered able to overcome the problem of information asymmetry that occurs due to differences in interests between management and investors, besides Shan et al. (2015) revealed that the use of XBRL could help regulators in using financial assistance. Indonesia has a specific type of binding regulation in the financial industry. The financial industry regulates settlement so that it can run well. The financial industry has an important role in managing the stability of the country. Therefore the financial industry must support the linking.

The role of the XBRL reporting format will be important, because XBRL has a significant impact in reducing information asymmetry and increasing the analysis estimates that companies can use to carry out planning (Liu et al., 2017). But there are other views from Harris \& Morsfield (2012) that XBRL presents limitations on companies that can be relied on by investors in analyzing decision making.

Banking is one of the sub-sectors of the financial industry, and banking has a substantial interest in supporting stability. Banking in Indonesia has regulations in classifying its industry into business categories. Each difficulty will be assessed based on core capital, number of offices, business plans, and business activities. The quality of financial statements issued by each bank varies, but Harymawan and Nurillah (2017) reveal that companies with higher levels of achievement will have higher quality financial reports.

Banking is a business sector that runs its business processes using the principle of prudence. In carrying out its business processes, banks will use and produce quality information (Latumaerissa, 2017, p. 90). As explained in the Financial Services Authority Regulation No. 6 / POJK.03 / 2016 concerning business and office networks based on bank core capital, this regulation explains that banks are classified into several levels. The core of the classification is based on core capital, business activities, business plans, and branch offices. Shan et al. (2015) say that the higher the level of capital of an organization/company, the better the information generated from financial statements because they have better resources compared to companies that have less capital. It is different from that expressed by Garbellotto (2009) that the application of capital/ resources owned depends on how the company implements the strategy. It is interesting because there are still differences of opinion regarding the effects generated by the two variables. 
The XBRL-based reporting format is gaining popularity in the world. There have been several researchers who have focused on examining the effect of XBRL on the quality of financial statements. As research conducted by Liu et al. (2014), which says that the adoption of XBRL will increase the accuracy of the analysis estimates, which means the information produced will be of high quality. Furthermore, research from Gandoman (2014) resulted in the finding that the application of the XBRL reporting format was required to increase transparency, efficiency in making decisions and in making accounting processes easier. The results of this study illustrate how the XBRL format influences the quality of financial statements.

When a company has sufficient resources, the company will produce quality information as much as possible. As Shan et al. (2015) revealed that a company/organization has sufficient resources, the organization/company will have sufficient resources to produce quality information. The role of the XBRL reporting format will be important because XBRL has a significant impact on reducing information asymmetry and increasing the analytical estimates that companies can use for planning (Liu et al., 2014). However, there are other views from Harris \& Morsfield (2012) that XBRL says presents limitations on companies that can be relied on by investors in analyzing decision making.

This study discusses to analyze the effect of financial to financial statements produced using the XBRL report format. Based on the literature review and research results, the research on this research will be seen in the figure:

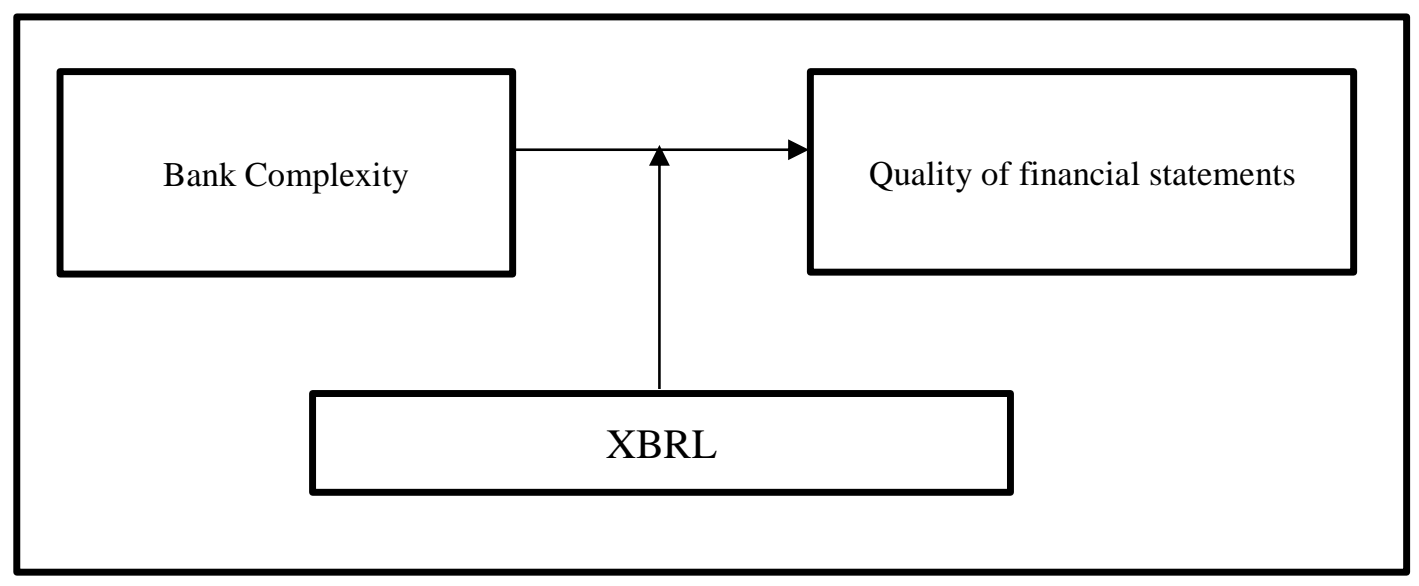

Figure 1. Research Model

\section{METHOD}

The object of this research is the complexity of the banking business on the quality of financial statements measured using non-discretionary accruals, the effect of the relationship will be strengthened or weakened by the implementation of the XBRL reporting format for banking companies listed on the Indonesia Stock Exchange in 2016.

According to Sugiyono (2014, p. 24), the research method is a scientific method used to obtain data with a specific purpose and frequency from that data. Based on this statement, a conclusion can be drawn that several keys can be considered, namely, the scientific method, data, objectives, and uses. Scientifically, it also means that research activities must be based on a scientific characteristic that is rational, empirical, and systematic in its structure.

In this study, the authors used the verification method with a quantitative approach in testing the independent variables and the dependent variables that have factors to strengthen or weaken the relationship between the two. According to Indriantoro and 
Supomo (2011, p. 40), quantitative research is research that will emphasize the process of testing theories through the measurement of research variables by interpreting numbers and analyzing data with statistical procedures.

Variable is an object, attribute or value of people, objects or activities that have a variety of variations between one another (Sekaran, 2006, p. 59). The factor of this variable is the XBRL reporting format that strengthens or weakens the relationship between the complexity of the banking business and the quality of financial statements.

This research was conducted by analyzing annual report data (annual report), analyzing data usage of XBRL format, and classifying banks according to their complexity group. All data was taken in 2016. The 2016 election is intended to see the effect of using the XBRL format. In 2016, diversity can still be found in usage. The diversity of using the data format the author uses to see variations in influence between those who use and who do not use.

\section{Calculating Bank Complexity}

Banking complexity is a grouping made by the government through the Financial Services Authority Regulation Number 6 / PJOK.03 / 2016 by considering various aspects such as core capital, business activities, office networks, and bank business plans going forward.

Measurement of the complexity of the banking business seen from BOOK 1, BOOK 2 , BOOK 3 , and BOOK 4, each of these groups will be represented by nominal 1, 2, 3, and 4. The scale used is the interval.

\section{Calculating XBRL}

The XBRL reporting format is new in reporting companies listed on the Indonesia Stock Exchange. This format directly changes the way users of financial statements conduct analysis and make decisions (Perdana et al., 2015). Variable format reporting XBRL is required using dummy variables. If the company reports in the XBRL format, it will be given a value of 1, and if it is not recommended that the XBRL format will be given a value of 0 . The scale used in the calculation is nominal.

\section{Calculating Financial Statements Quality}

Good quality reports will present information that can be agreed to make decisions by the user (Rahmawati, 2012, p. 60). Non-discretionary accruals are calculated by reducing total accrual banking in accordance with 2016 with discretionary accruals on related banks in 2016.

Calculate Total Accruals (TO) and Non-Discretionary Accruals to get the value of discretionary accrual periods that can be determined by the following equation:

1)

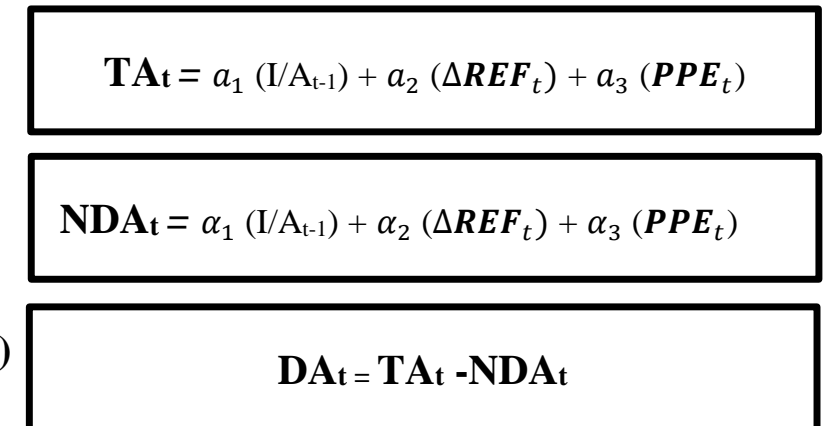

Where
DA
: Discresionary Accrual

153 | The International Journal of Business Review (The Jobs Review) Vol.2 | No.2 | 2019 
TA : Total Accruals

NDA : Non-Discresionarry Accrual

$\triangle \mathrm{REV}_{\text {it }} \quad$ : Net income for company i period $\mathrm{t}_{1}$

$\mathrm{PPE}_{\mathrm{it}} \quad:$ The value of the company's fixed assets $\mathrm{i}$ in period $\mathrm{t}$

$\mathrm{A}_{\mathrm{i}, \mathrm{t}-1} \quad$ : Total assets of company $\mathrm{i}$ in period $\mathrm{t}_{1}$

$a_{1}, a_{2}, a_{3} \quad$ : Company parameters

\section{Control variables: Firm Size}

Firm Size is describing the size of a company, which is shown in total assets, total sales, average sales, and total assets. In this study, the authors used the natural logarithm of total assets. The use of natural logarithms is intended to equalize the format used in calculations that are to use ratios, so the value obtained will be converted to Natural Logarithms with ratio format.

Firm size = Ln Total Assets

\section{Empirical model}

This study uses multiple regression models with the following equation:

$$
\widehat{\mathbf{Y}}=\beta_{0}+\beta_{1} \mathbf{X}_{1}+\beta_{2} \mathbf{X}_{2}+\beta_{3} \mathbf{X}_{1} \cdot \mathbf{X}_{2}+\beta_{4} \mathbf{X}_{3}+\boldsymbol{\varepsilon}
$$

$\begin{array}{ll}\text { Where } & \\ \widehat{\mathbf{Y}} & : \text { Financial Statement Quality } \\ \beta_{\mathbf{0}} & : \text { Constanta } \\ \beta_{\mathbf{i}} & \text { : Regression coefficient of the independent variable, =1,2,3,4 } \\ \mathbf{e} & : \text { error } \\ \mathbf{X}_{\mathbf{1}} & : \text { Bank Complexity } \\ \mathbf{X}_{\mathbf{2}} & : \text { XBRL } \\ \mathbf{X}_{\mathbf{3}} & : \text { XBRL moderation } \\ \mathbf{X}_{\mathbf{4}} & : \text { Firm Size }\end{array}$

\section{Sample selection and descriptive statistics}

The sample is part of the population. Therefore sampling aims to draw conclusions that can be generalized to the population (Sudaryono, 2017, p. 31). In this study, the authors used purposive sampling to determine the sample taken. Purposive sampling is a technique for determining the sampling technique chosen by a sample determination technique with certain considerations or criteria (Sudaryono, 2017, p. 31). Based on the description, the sample criteria determined in this study are:

\section{Banking companies listed on the Indonesia Stock Exchange in 2016.}

Based on the specified sample criteria, 42 companies were sampled in this study. The technique in descriptive statistics is to process raw numerical data into forms that can be used, including methods of collecting, organizing, summarizing, depicting, and presenting statistical information (Cahyono, 2015, p. 43).

\section{Descriptive statistics}

Description of variables is done to get an overview of each variable, namely the complexity of the banking business, XBRL reporting format, and the quality of financial 
statements. Descriptive analysis of the variable data of this study explains the standard deviation, the mean value, the minimum value, and the maximum value of the independent variable and the dependent variable. Descriptive statistics of the research variables can be seen in the following explanation:

Table 1. Descriptive Statistics

\begin{tabular}{|l|r|r|r|r|r|}
\hline & N & Min & \multicolumn{1}{c|}{ Max } & Mean & Std. Deviation \\
\hline Bank Complexity & 42 & 1 & 4 & 2,43 &, 590 \\
\hline XBRL & 42 & 0 & 1 &, 55 &, 504 \\
\hline $\begin{array}{l}\text { Financial Statement } \\
\text { Quality }\end{array}$ & 42 &, 001 &, 585 &, 14705 &, 154163 \\
\hline Leverage & 42 &, 045 & 2,876 &, 73119 &, 549348 \\
\hline Profitability & 42 &,- 053 &, 209 &, 02656 &, 050128 \\
\hline Firmsize & 42 & 25,261 & 29,589 & 27,33144 & 1,141550 \\
\hline Moderation & 42 &, 000 & 4,000 & 1,35714 & 1,340212 \\
\hline Valid N (listwise) & 42 & & & & \\
\hline
\end{tabular}

In this study, banking complexity uses the natural logarithm of the BOOK level. BOOK level determines the results of the number of business activities, business plans, number of branches, and total core capital (Financial Services Authority, 2015, p. 40). The higher this ratio, the better the company will be more complex. The maximum value ( $\max$ ) obtained from the calculation of business complexity is 4 / BOOK 4 . The average value (Mean) of the complexity of the banking business is two obtained from 42 banking companies. The result is that because there are 19 companies classified as BOOK 2 (Data not tabulated).

The second variable in this study is XBRL. XBRL is a financial reporting format based on the XML language. The XML language base is modified and adapted to business needs so that it can meet the wishes of all parties (Shan \& Troshani, 2016). A calculation indicator obtained using the payment format mentioned in the financial statements on the IDX website. Companies that use XBRL in their financial statements will attach a particular file that contains financial statements in XML format. The data shows that most banking companies listed on the stock exchange in 2016 have used the XBRL reporting format. 2016 is the second year on the Indonesian stock exchange in implementing the XBRL reporting format. Banks that have adopted xbrl exceed 50 percent of the population. Seen from the average value of 0,55

The third variable in this study is the quality of financial statements. The financial statements prepared must be able to present factual, accurate, objective, and informative information (Yadiati, 2010, p. 72). This variable is measured using the discretionary accruals model of Jones (1991). To get the results of discretionary accruals, Belkaoui (2007) recommends to do the following steps according to the model of Jones:

1. Entering data from each banking financial report in 2016.

The data entered in the form of:
a. Total Assets
b. Plant Assets
c. Total Revenue

2. After the required data has been obtained, the next step is to enter these values into the formula: 
1)

$\mathbf{T A}_{\mathbf{t}}=a_{1}\left(\mathrm{I} / \mathrm{A}_{\mathrm{t}-1}\right)+a_{2}\left(\Delta \boldsymbol{R} \boldsymbol{E} \boldsymbol{F}_{t}\right)+a_{3}\left(\boldsymbol{P P} \boldsymbol{E}_{t}\right)$

2)

$\mathbf{N D A t}_{\mathbf{t}}=\alpha_{1}\left(\mathrm{I} / \mathrm{A}_{\mathrm{t}-1}\right)+\alpha_{2}\left(\boldsymbol{R} \boldsymbol{E} \boldsymbol{F}_{t}\right)+\alpha_{3}\left(\boldsymbol{P P} \boldsymbol{E}_{t}\right)$

3)

$$
\text { DAt }=\text { TAt }- \text { NDAt }
$$

The maximum value (maximum) on the quality of financial statements is 0,585 and minimum value on the quality of financial statement is 0,001 . The standard deviation (standard deviation) of the quality of the financial statements is 0,154163 the results of which are shown indicate higher average values with the standard The deviation used is the result of the distribution of sample data to spread/vary from the average. The difference in the value of financial statements is related to differences in the characteristics and differences of each of the banking companies.

\section{RESULTS AND DISCUSSION}

Tabel 3. Multiple Linear Regression Eviews Output

\begin{tabular}{|c|r|r|r|r||}
\hline Variable & Coefficient & Std. Error & t-Statistic & Prob. \\
\hline C & 0.351146 & 0.178675 & 1.965278 & 0.0569 \\
\hline COMPLEXITY & -0.086114 & 0.032085 & -2.683922 & $0.0108 *$ \\
\hline XBRL & -0.062574 & 0.097672 & -0.640652 & $0.0257 *$ \\
\hline MODERATION & 0.019536 & 0.042374 & 0.461045 & $0.0475 *$ \\
\hline FIRM_SIZE & -0.006941 & 0.006078 & -1.142044 & $0.0608 * *$ \\
\hline R-squared & 0.441030 & Mean dependent var & -0.068339 \\
\hline Adjusted R-squared & 0.380601 & S.D. dependent var & 0.110919 \\
\hline S.E. of regression & 0.087296 & Akaike info criterion & -1.927690 \\
\hline Sum squared resid & 0.281959 & Schwarz criterion & -1.720824 \\
\hline Log likelihood & 45.48148 & Hannan-Quinn criter. & -1.851865 \\
\hline F-statistic & 7.298290 & Durbin-Watson stat & 1.360878 \\
\hline Prob(F-statistic) & 0.000194 & & \\
\hline
\end{tabular}

Where :

** : Significance at the $10 \%$ level $(0.10)$

* : Significance at the $5 \%$ level $(0.05)$

In the table 3, it can be seen the results of the regression conducted for the 2016 banking financial statement data. From the table 3, it can be seen that the complexity of the banking business obtains a significant value of significance at the 5\% level of 0.0108 , the XBRL variable obtains a significant significance value at the 5\% level at the level of 0.0257 . The result of the moderating variable between the complexity of the banking business and XBRL, which is proxied by moderation, has a significant significance value of 0.0475 . In 
addition to the main variable, there is one control variable used in this study. First, the company size variable, which is proxied to the size of the company, obtained significance at the $10 \%$ level of 0.0608 . Then the regression equation can be formed as follows:

Financial Statements quality $=0.351146+(0.0108)($ complexity $)+(0.0257)($ xbrl $)+$ $(0.0475)($ moderation $)+(0.0608)($ decisive $)+e$

\section{Hypothesis test}

Based on the results of the regression conducted on the data that has been collected, it can be concluded from the hypothesis test of each independent of the dependent variable. Testing the hypothesis in this study are as follows:

\section{Research Hypothesis 1: The complexity of the banking business has a positive effect on the quality of financial statements}

The business complexity variable has a significance value of 0.0108 and has a regression coefficient of -0.086114 . The significance value of this variable becomes significant at the $5 \%$ level. Then the regression coefficient of -0.086114 , which is smaller than 0,000 indicates a negative direction. The negative direction has the opposite understanding because the measurement tools for the quality of financial statements that are used are nondiscretionary accruals so that when a large value means getting worse and when the value is small, the better. According to the following explanation, it can be concluded that in this study reject $\mathrm{H} 0 ; 1$ and accept $\mathrm{Ha} ; 1$ or it can be said that the variable complexity has a positive effect on the quality of financial statements. Every increase of one unit of banking business complexity will cause an increase in the quality of the financial statements, which is set at -0.086114 units assuming the other variables are fixed.

The value of discretionary accruals shows an indicator of the quality of financial statements owned. The higher the value, the higher the accrual policy taken by the company. Therefore, the value of small discretionary accruals indicates the better the quality of the financial statements. The calculations result concludes that when banking is more complex, it will affect the quality of financial statements that are getting better. It also applies to the contrary. When banking is less complex, it will affect the quality of financial statements that are not good.

The banking complexity will also directly show the value of core capital, the number of business activities, office networks, and future business plans. The more complex the bank will have large core capital, complete business activities, extensive office network, and sustainable business plans. However, the larger a company, the greater the conflict of interest as agency theory explained. Agency theory states that in carrying out the activities of a company, agency problems often arise, namely asymmetry of information. So that these problems can be resolved, the company management has an obligation to publish information about the actual condition of the company to investors as shareholders (Anthony \& Govindarajan, 2012).

Companies with higher banking business complexity have lower average discretionary accruals, meaning that the more complex a bank will have, the better the quality of financial statements.

This research is in line with research conducted by Heryawan and Nurillah (2017); Shan et al. (2015); Blankespoor et al. (2014); Gras-Gil et al. (2012) which states that the increasingly complex business has a negative effect on the quality of poor financial statements. However, this study is not in line with the research of Johl et al. (2013) and Yasser et al. (2017) that state the business complexity has a positive effect on the quality of 
financial statements. It is because the more complex companies will directly increase the risk of reporting, therefore, can positively influence the quality of financial statements.

\section{Research Hypothesis 2: The application of the XBRL reporting format has a positive effect on the quality of financial statements}

The XBRL reporting format variable has a significance value of 0.0257 and has a regression coefficient value of -0.06257 . The significance value of this variable becomes significant at the $5 \%$ level. Then the regression coefficient value of -0.06257 , which is smaller than 0.000 indicates a negative direction. The negative direction has the opposite understanding because the measurement tools for the quality of financial statements that are used are nondiscretionary accruals so that when a large value means getting worse and when the value is small, the better. According to the following explanation, it can be concluded that in this study rejecting H0: 1 and accepting Ha; 1 or it can be said that the variable reporting format XBRL has a positive effect on the quality of financial statements. Every increase of one unit from the XBRL reporting format will cause an increase in the quality of the financial statements, which is set at -0.06257 units assuming the other variables are fixed. The implementation of XBRL in Indonesia is effective in 2016. It is a reason there are still many companies that have not used the XBRL format in their reporting.

The results showed that the XBRL reporting format has a positive effect on the quality of financial statements, meaning that when the XBRL reporting format is used, it will reduce the possibility of an accrual policy from management so as to improve the quality of financial statements.

The use of XBRL in reporting financial statements will improve operational efficiency, transparency and decision making (Gandoman \& Rostami, 2014). XBRL is considered to be used as a method of accountability to shareholders because of differences in interests between management and shareholders expressed in agency theory. Agency theory explains that there are differences in interests between the management and the shareholders. The role of XBRL is to serve information in order to be fully accepted by the shareholders. The shareholders need this information to analyze the activities of management. On the contrary, the management needs to report the results of its activities contained in financial or annual reports to account for its activities within a specified period.

Companies that use financial reporting formats with XBRL have a greater value in the quality of financial statements compared to those that do not use XBRL. It can be interpreted that the banks that report financial statements using XBRL have better quality financial statements compared to those who do not use XBRL.

The results of this study are in line with research conducted by Gandoman and M. Rostami (2014) and Shan et al. (2015), which state that XBRL has the effect of improving the quality of financial statements. However, this study is not in line with research conducted by Blankespoor et al. (2014), which states that XBRL has a negative influence on the quality of financial statements.

Research Hypothesis 3: The effect of the complexity of the banking business on the quality of financial statements will be stronger with the application of the XBRL reporting format

The moderating variable of applying the XBRL reporting format and the complexity of the banking business has a significance value of 0.0475 and has a regression coefficient value of 0.01953 . The significance value of this variable becomes significant at the $5 \%$ level. Then the regression coefficient value of 0.01953 , which is greater than 0.000 indicates a positive direction. This means that rejecting $\mathrm{H} 0 ; 1$ and accepting $\mathrm{Ha} ; 1$ or it can be said that 
the moderation variable XBRL reinforces the influence of the complexity of the banking business on the quality of financial statements. Every increase of one unit of the XBRL moderation variable will cause a strengthening effect on the quality of the financial statements, which is set at 0.01953 units assuming the other variables are fixed.

Testing the effect of the XBRL reporting format as moderation on financial reporting shows that the XBRL reporting format has a positive effect on the relationship between the complexity of the banking business and the poor quality of financial statements. That is if banks are increasingly complex and using financial reporting formats with XBRL will have better complexity.

The results of this study are in line with research conducted by Gandoman \& Rostami (2014) and Shan et al. (2014), which state that the moderating effect of XBRL on increasingly complex banking will reduce the quality of financial statements. However, this research is not in line with research conducted by Blankespoor et al. (2014) and Shan \& Troshani (2016), which state that the application of XBRL to complex banking will improve the quality of financial statements.

\section{CONCLUSION}

Based on the results of research and discussions that have been conducted regarding the comparison of the banking business to the quality of financial statements moderated by the XBRL reporting format on the Indonesia Stock Exchange (BEI) in 2016, conclusions can be drawn as follows (1) The complexity of positive financial business. The complexity of the banking business is positive for the quality of financial statements. These results will increase the value of the banking business will increase the value of the quality of financial statements (2) The application of the XBRL reporting format has a positive impact on the quality of financial statements. XBRL reporting format has a positive impact on the quality of financial statements. These results report that the compilation of banks using the XBRL reporting format improves the quality of financial statements (3) The influence of the banking business on the quality of financial statements will be stronger with the application of the XBRL format. Influencing the banking business on the quality of financial statements is getting stronger with moderation from XBRL. These results prove that the compilation of XBRL formats used by banks is more complicated, so the quality of financial statements will improve.

Recommendation. After testing, obtaining research results and concluding from the influence of the complexity of the banking business on the quality of financial statements moderated by the XBRL reporting format, the authors present several recommendations and their implications for related parties as follows (1) For Banks. Based on the results of research that has been conducted, the complexity of the banking business has a positive effect on the poor quality of financial statements. It recommends banks that still have a business complexity that is still lacking, to continue increasing the level of the BOOK. Not only does it increase complexity, companies must have quality financial reports to attract new investors and retain old investors. Furthermore, the effect of using the XBRL reporting format on the quality of financial statements has a positive effect. It recommends banks that have not reported financial reports with XBRL to make an XBRL version, to provide assurance and convenience for investors in using the data. In addition, other benefits for banks are being able to process data quickly and accurately and can attract new investors if the quality of the report is better than before. (2) For the Indonesia Stock Exchange (IDX). Based on the results of research, the effect of the complexity of the banking business on the quality of financial statements weakened due to moderation by the XBRL reporting format. It recommends the IDX to adjust the tags in the IDXnet system to the needs and common good so that the results of the application format XBRL reporting can be maximized for the 
benefit of all parties. (3) For further researchers. For further researchers, this research is expected to be a reference in research related to XBRL, banking, and financial report quality. Future studies are expected to be able to add and use other indicators or be able to compare their effects with the year before or after the implementation of XBRL.

\section{REFERENCES}

Anthony, R. N., \& Govindarajan, V. (2012). Management Control System. Jakarta: Salemba Empat.

BEI. (2014). Pengenalan XBRL dan Implementasi XBRL di BEI. Indonesia.

BEI. (2018). Laporan keuangan perusahaan yang listing. Jakarta.

Belkaoui, A. R. (2007). Accounting Theory (2nd ed.). Jakarta: Salemba Empat.

Bhattacharya, N., Desai, H., \& Venkataraman, K. (2013). Does Earnings Quality Affect Information Asymmetry? Evidence from Trading Costs, 30(2), 482-516. https://doi.org/10.1111/j.1911-3846.2012.01161.x

Blankespoor, E., Miller, B. P., \& White, H. D. (2014). Initial evidence on the market impact of the XBRL mandate. Review of Accounting Studies, 19(4), 1468-1503. https://doi.org/10.1007/s11142-013-9273-4

Boritz, J. E., \& No, W. G. (2009). Assurance on XBRL-related documents: the case of United Technologies Corporation. Journal of Information System, 23(2), 49-78.

Byard, D., \& Cebenoyan, F. (2012). Article information: Alternative evidence on financial analysts' use of financial statement information. Review of Accounting and Finance, $6(4), 442-459$.

Cahyono, T. (2015). Statistik Uji Normalitas. Purwokerto: Yasamas.

Dangolani, S. K. (2011). The impact of information technology in banking system (a case study in Bank Keshavarzi IRAN). Procedia - Social and Behavioral Sciences, 30, 1316. https://doi.org/10.1016/j.sbspro.2011.10.003

Dykes, L., \& Tittel, E. (2005). XML For Dummies (4th ed.). Indianapolis: Wiley Publishing.

Financial Service Authority. (2015). POJK nomor 6/POJK.03/2016. Indonesia. https://doi.org/10.9790/0853-1702091216.

Gandoman, S. H., \& Rostami, M. (2014). Investigating the effect of Extensible Business Reporting Language (XBRL) on quality improvement of financial reporting in Iranian corporations, $1-14$.

Garbellotto, G. (2009). XBRL implementation strategies: The bolt-on approach”, Strategic. Finance, May.

Gramling, J. A. A., \& Bailey, A. D. (2015). Research on Professional Responsibility and Ethics in Accounting Article information

Gras-Gil, E., Marin-Hernandez, S., \& de Lema, D. G. (2012). Internal Audit and Finansial Reporting in the Spanish Banking Industry. Managerial Accounting Journal, 27(1), 728-753. https://doi.org/10/1018/02686901211257028.

277Harahap, S. S. (2010). Teori Akuntansi. Jakarta: Rajagrafindo.

Harris, T. S., \& Morsfield, S. G. (2012). An evaluation of the current state and future of XBRL and interactive data for investors and analysts. Http://Hdl.Handle.Net/10022/AC:P:20283.

Harymawan, I., \& Nurillah, D. (2017). Do Reputable Companies Produce a High Quality of Financial Statements?

Indriantoro, N., \& Supomo, B. (2011). Metodologi Penelitian bisnis untuk Akuntansi dan Manajemen (1st ed.). Yogyakarta: BPEE Yoyakarta.

Iskandar, S. (2008). Bank dan Lembaga Keuangan Lainya. Jakarta: Semesta Asa Bersama. 
Johl, S. K., Subramaniam, N., \& Cooper, B. (2013). Internal Audit Function, board quality and financial reporting quality: evidence from Malaysia. Managerial Auditing Journal, 28(9), 780-814. https://doi.org/10/1108/MAJ-06-2013-0886.

Kardan, B., Salehi, M., \& Abdollahi, R. (2016). The relationship between the outside financing and the quality of financial reporting: evidence from Iran. Journal of Asia Business Studies, 10(1), 20-40. https://doi.org/10.1108/JABS-04-2014-0027

Kasmir. (2008). Bank dan Lembaga Keuangan Lainya (Edisi Revi). Jakarta: PT. RajaGrafindo Persada.

Latumaerissa, J. R. (2017). Bank dan Lembaga Keuangan lainya. Jakarta: Mitra Wacana media.

Lim, J., Lee, J., dan Chang, J. (2015). Article information: Financial reporting quality of target companies and acquirer: evidence from korea. International Journal of Accounting dan Information Management, 23(1).

Liu, C., Luo, X. R., \& Wang, F. L. (2017). An empirical investigation on the impact of XBRL adoption on information asymmetry: Evidence from Europe. Decision Support Systems, 93, 42-50.

Perdana, A. (2014). Extensible business reporting language (xbrl): Implikasi Pada Paradigma dan Rantai Pasok Pelaporan Keuangan, 15(1), 23-40.

Perdana, A., Robb, A., \& Rohde, F. (2015). An Integrative review and synthesis of XBRL research in academic journals. Journal of information system, 29(1), 115-153.

Rahmawati. (2012). Teori Akuntansi Keuangan. Yogyakarta: Graha Ilmu.Sudana.

Shan, Y. G., \& Troshani, I. (2016). International Journal of Managerial Finance The effect of mandatory XBRL and IFRS adoption on audit fees: Evidence from the Shanghai Stock Exchange. International Journal of Managerial Finance Iss International Journal of Managerial Finance, 12(2). https://doi.org/10.1108/IJMF-12-2013-0139

Shan, Y. G., Troshani, I., \& Richardson, G. (2015). Journal of Contemporary Accounting dan Economics An empirical comparison of the effect of XBRL on audit fees in the US and Japan. Journal of Contemporary Accounting dan Economics, 11(2), 89-103. https://doi.org/10.1016/j.jcae.2015.01.001

Steenkamp, L. P., \& Nel, G. F. (2012). The adoption of XBRL in South Africa: An empirical study. Electronic Library, 30(3), 409-425. https://doi.org/10.1108/02640471211241672

Subramanyam, K. R., \& Wild, J. J. (2010). Analisis Laporan Keuangan (10th ed.). Jakarta: Salemba Empat.

Sudaryono. (2017). Metodologi Penelitian (2nd ed.). Depok: Rajagrafindo.

Sugiyono. (2014). Statistika untuk Penelitian. Bandung: Alfabeta.

Sekaran, U. (2006). Metodologi Penelitian untuk Bisnis (4th ed.). Jakarta: Salemba Empat.

Yadiati, W. (2010). Teori Akuntansi: Suatu Pengantar. Jakarta: Kencana Prenada Media Group.

Yasser, Q. R., Al Mamun, A., \& Hook, M. (2017). The impact of ownership structure on financial reporting quality in the east. International Journal of Organizational Analysis, 25(2), 178-197. https://doi.org/10.1108/IJOA-08-2015-0894. 


\section{ATTACHMENTS}

\section{Bank Complexity}

\begin{tabular}{|c|c|c|c|c|}
\hline Sample & Complexity & Main Capital & $\begin{array}{c}\text { business } \\
\text { activities }\end{array}$ & Office \\
\hline 1 & 1 & 1.108 .216 .006 .380 & 7 & National \\
\hline 2 & 1 & 446.078 .173 .585 & 7 & National \\
\hline 3 & 1 & 572.506 .000 .000 & 7 & National \\
\hline 4 & 1 & 1.315 .040 .000 .000 & 7 & National \\
\hline 5 & 1 & 4.411 .890 .000 .000 & 7 & National \\
\hline 6 & 2 & 1.197 .510 .000 .000 & 8 & National \\
\hline 7 & 2 & 1.936 .251 .540 .000 & 8 & National \\
\hline 8 & 2 & 1.860 .405 .000 .000 & 8 & National \\
\hline 9 & 2 & 2.681 .773 .809 .235 & 8 & National \\
\hline 10 & 2 & 643.065 .256 .027 & 8 & National \\
\hline 11 & 2 & 1.296 .667 .409 .954 & 8 & National \\
\hline 12 & 2 & 4.475 .322 .000 .000 & 8 & National \\
\hline 13 & 2 & 2.626.270.697.000 & 8 & National \\
\hline 14 & 2 & 4.424 .389 .000 .000 & 8 & National \\
\hline 15 & 2 & 998.153 .000 .000 & 8 & National \\
\hline 16 & 2 & 1.067 .856 .000 .000 & 8 & National \\
\hline 17 & 2 & 482.705 .000 .000 & 8 & National \\
\hline 18 & 2 & 3.477 .929 .000 .000 & 8 & National \\
\hline 19 & 2 & 1.111 .612 .136 .000 & 8 & National \\
\hline 20 & 2 & 203.212 .000 .000 & 8 & National \\
\hline 21 & 2 & 1.331 .757 .000 .000 & 8 & National \\
\hline 22 & 2 & 34.200 .800 .000 .000 & 8 & National \\
\hline 23 & 3 & 2.396 .184 .000 .000 & 9 & National \\
\hline 24 & 3 & 12.265 .680 .418 .876 & 9 & National \\
\hline 25 & 3 & 19.506 .576 .000 .000 & 9 & National \\
\hline 26 & 3 & 9.674 .228 .000 .000 & 9 & National \\
\hline 27 & 3 & 7.209.572.000.000 & 9 & National \\
\hline 28 & 3 & 36.377 .972 .000 .000 & 9 & National \\
\hline 29 & 3 & 864.579 .000 .000 & 9 & National \\
\hline 30 & 3 & 2.254.646.000.000 & 9 & National \\
\hline 31 & 3 & 2.501 .014 .000 .000 & 9 & National \\
\hline 32 & 3 & 19.289 .606 .000 .000 & 9 & National \\
\hline 33 & 3 & 34.207 .622 .000 .000 & 9 & National \\
\hline 34 & 3 & 19.272 .606 .000 .000 & 9 & National \\
\hline 35 & 3 & 146.812 .590 .000 .000 & 9 & National \\
\hline 36 & 3 & 19.130 .536 .000 .000 & 9 & National \\
\hline 37 & 3 & 89.254 .000 .000 .000 & 9 & National \\
\hline 38 & 3 & 6.910 .000 .000 .000 & 9 & National \\
\hline 39 & 3 & 34.207 .622 .000 .000 & 9 & National \\
\hline 40 & 3 & 19.272 .606 .000 .000 & 9 & National \\
\hline 41 & 3 & 153.369 .723 .000 .000 & 9 & National \\
\hline
\end{tabular}

162 | The International Journal of Business Review (The Jobs Review) Vol.2 | No.2 | 2019 


\begin{tabular}{ccccc}
\hline Sample & Complexity & Main Capital & $\begin{array}{c}\text { business } \\
\text { activities }\end{array}$ & Office \\
\hline 42 & 4 & 676.738 .753 .000 .000 .000 & 9 & International \\
\hline
\end{tabular}

2. Use of XBRL

\begin{tabular}{cccccc}
\hline Sample & XBRL & Sample & XBRL & Sample & XBRL \\
\hline 1 & Yes & 15 & No & 29 & No \\
2 & No & 16 & Yes & 30 & Yes \\
3 & No & 17 & Yes & 31 & Yes \\
4 & Yes & 18 & Yes & 32 & No \\
5 & No & 19 & Yes & 33 & No \\
6 & No & 20 & No & 34 & Yes \\
7 & Yes & 21 & No & 35 & Yes \\
8 & No & 22 & Yes & 36 & Yes \\
9 & No & 23 & Yes & 37 & Yes \\
10 & No & 24 & No & 38 & No \\
11 & No & 25 & Yes & 39 & Yes \\
12 & No & 26 & Yes & 40 & No \\
13 & No & 27 & Yes & 41 & No \\
14 & Yes & 28 & No & 42 & No \\
& & & & & \\
\hline
\end{tabular}

3. Quality of Financial Statements

\begin{tabular}{crcc}
\hline Sample & Quality & Sample & Quality \\
\hline 1 & $-0,1100685688$ & 22 & $-0,140072989$ \\
2 & 0,0520616898 & 23 & $-0,449355243$ \\
3 & 0,0743675328 & 24 & $-0,089308921$ \\
4 & $-0,0000836142$ & 25 & $-0,057136266$ \\
5 & $-0,0676447512$ & 26 & $-0,016964099$ \\
6 & $-0,1003655202$ & 27 & 0,0407150532 \\
7 & $-0,1582406698$ & 28 & $-0,121883441$ \\
8 & $-0,1449606613$ & 29 & 0,1810473878 \\
9 & 0,0000000000 & 30 & $-0,035714566$ \\
10 & $-0,0113747087$ & 31 & $-0,089859719$ \\
11 & $-0,0856865349$ & 32 & $-0,200319910$ \\
12 & $-0,0552580106$ & 33 & $-0,354779475$ \\
13 & 0,0403293356 & 34 & $-0,181926270$ \\
14 & $-0,0492701749$ & 35 & $-0,342251666$ \\
15 & $-0,0258087032$ & 36 & $-0,065875774$ \\
16 & $-0,0536570842$ & 37 & $-0,051391085$ \\
17 & $-0,1090154090$ & 38 & $-0,208951576$ \\
18 & $-0,0556599716$ & 39 & $-0,215216539$ \\
19 & $-0,0556599716$ & 40 & 0,0735262425 \\
20 & 0,1228076633 & 41 & $-0,052034606$ \\
21 & $-0,2098266566$ & 42 & 0,1307925152 \\
\hline
\end{tabular}

